Research Article

\title{
Public Opinions, Preparedness and Perspectives Regarding COVID-19 Pandemic Future in India
}

Dr. Monika Singla ${ }^{1 *}$ and Bhavya Bansal ${ }^{2}$

IMD, DM, Associate Professor, Department of Neurology, Dayanand Medical College and Hospital, Ludhiana, Punjab, India

${ }^{2}$ Student, 9th Grade, India Book of Record Holder, 2019, Sat Paul Mittal School, Ludhiana, Punjab, India

Corresponding Author: Dr. Monika Singla, E-mail: drmonika78@yahoo.com

\begin{tabular}{l} 
ARTICLE INFO \\
\hline Article History \\
Received: August 03, 2020 \\
Accepted: September 12, 2020 \\
Volume: 2 \\
Issue: 5 \\
\hline KEYWORDS \\
\hline
\end{tabular}

COVID-19, Public health, social issues, economy, future perspectives

\section{ABSTRACT}

COVID-19 pandemic has globally affected the health, economy, psychology and socio-economic status of the society. This pandemic demands a great deal of preparedness by public at many fronts. To control this pandemic India implemented a complete lockdown in the whole country. Post unlock there are rapidly rising number of cases, therefore we planned to conduct an online survey on general public regarding their thoughts on COVID-19 in the coming times. We planned to ask them few questions regarding their take on pandemic in coming months, their economic status, stigma regarding health of their family and their suggestions regarding control of pandemic, if lockdown should be implemented or not despite fall in business and economy. It was circulated through messages to various groups and people and they were requested to fill it. On analyzing the survey responses, majority of the people mentioned that pandemic is going to increase and most of the people were concerned about their family's health. More than $50 \%$ admitted that they will change their lifestyle and reduce their expenses. Though loss of economy is there, many people favored reimplementation of lockdown to stop spread of the virus. We concluded with this survey that besides effect on physical and mental health of people, there is significant effect on social health and economic aspects of people. With time people are getting clear about their futuristic approaches to handle this pandemic.

\section{Introduction}

In this COVID-19 pandemic, the rising number of daily cases has led to a lot of panic and stress in the community. There is rising number of depression cases because of stress of health of family, loss of jobs, poverty, falling personal income and economy of the country. There is disruption of lives of individuals and economies around the world in COVID-19 pandemic. According to Xiang YT et al., 2020 and Souvik Dubey et al., 2020, besides physical and mental health, COVID-19 pandemic has also severely impacted the economic, financial status and business of the country. It is very difficult for the developing as well the developed nations to sustain this virus as the costs involved in the treatment and containment of this viral illness are skyhigh. Virus is rapidly affecting large number of people. We need to understand the health of public and our health system. Though media is flooded with information regarding disease symptoms, its manifestations, hot spot areas, falling economy etc., still public opinions are needed to deal with these current health management challenges, before the policy makers make new policies to handle this pandemic. Major research is going on development of medicines and vaccines for the prevention and treatment of this dreaded disease. As per New York Times, 2020, on 11 ${ }^{\text {th }}$ March, 2020, WHO declared COVID19 as a pandemic. COVID-19 has become an international emergency in a short period and supposed to have long-lasting effects. According to Gilbert M et al., 2020, there is an urgent need to identify and study the areas of academic research which will be impacted by COVID-19. According to Haleem M et al., 2020, there are many issues which need to be considered

\footnotetext{
K C AL-KINDI CENTER R D FOR RESEARCH AND
} Your gateway to world-class research
Published by Al-Kindi Center for Research and Development. Copyright (c) the author(s). This is an open access article under CC BY license (https://creativecommons.org/licenses/by/4.0/) 
and paid special attention like social issues related with this pandemic like maintaining social distancing, public gatherings, general awareness in the public regarding this disease, economic like manufacturing of products, market status, purchase and sale of goods, job status of people, financial loss as well as emotional and psychological impact like concern of family health and mental issues regarding this disease. These issues need to be sorted out slowly to overcome this pandemic

This manuscript highlights potential areas of academic research which are likely to be impacted by COVID-19. The main objectives of this study were to check awareness of public regarding future of pandemic, their knowledge about stopping spread of the virus, their expectations regarding development of vaccine. Their opinions regarding government policies for the need of lockdown implementation again as after unlock period, there is rapid rise in the number of cases in India were also asked. People were also requested to give suggestions to control the virus spread.

\section{Material and Methods}

We planned to conduct an online survey. We created an online questionnaire form. The form was framed in English as well as Hindi language. It was a short survey. The form consisted of six sections, first section included demographic profile of patients which included name (optional), age, country, state, occupation which was categorized into various occupations like professional (further categorized into doctor, paramedical, IT sector, hospitality, finance, human resource), teachers, police officers, businessmen, farmers, students, home-makers and others. The form consisted of ten questions, each question having four options. Second section included three questions which were regarding what they think regarding Covid-19 pandemic future, whether it is going to increase, decrease or will remain same, what they expect from life ahead, whether they need to take these days life as new normal, or it will change or come to normal soon, how much they are concerned about their family's health ahead? Third section included questions regarding their job and economics. They were asked how much they were stressed regarding retaining job or if they already lost it. They were also enquired how they will handle their financial matters in upcoming future, whether they will limit their expenses, as per their earning, or buy only necessary things, or spend liberally as life has become unpredictable or they won't change their lifestyle. Fourth section was regarding government policies, whether seeing the number of rising cases government should implement the lockdown again or it should be done only in high risk areas. Fifth section included questions regarding measures to be taken to help us in near future like wearing masks in public, social distancing or avoiding crowded places or nothing will help. In the last section, they were asked regarding future treatment therapies besides allopathic medicine if there is any role of homeopathic or ayurveda in COVID-19 treatment and what are their views regarding development of COVID-19 vaccine, when are they expecting it to come in the market. At the end of the questionnaire they were asked if they want to give any suggestions to people and authorities regarding this pandemic. This form was circulated through internet and messages in various official, friends and family groups. It was circulated through broadcast lists to various doctors, teachers, students, patients and public. Most of the people were motivated to participate in the survey through personal messages and they were requested to share with their friends and other people as much as possible. Most of the responses were gathered on first three days, though the link was continued for seven days. On day seven, survey was closed and analysis was started after downloading the data on Microsoft excel sheet.

\section{Statistical Analysis}

SPSS Statistics v25 and Excel (Office 365) were primarily used for analyzing data. Exploratory data analysis (EDA) was performed on explanatory variables (such as demographic variables). Distribution analysis was conducted on the independent variables using box-and-whisker plots to standardize the data and identify outliers. Once summary tables were generated using SPSS, the data was visualized using clustered bar charts and pie graphs.

\section{Observations and Results}

Total 1438 people participated in the survey. On downloading the details on the excel sheet, we realized that seven people didn't fill the complete survey, most the entries were vacant, therefore they were excluded from the analysis. 1431 patients were included in the final analysis. 1384 people were Indians from various states, maximum from Punjab, few from Himachal Pradesh, few from J\& K, Hyderabad, Madhya Pradesh, and few from Haryana. 47 people were non-resident Indians settled in USA, Canada, Florida, Nigeria, Australia and Singapore. Majority of the participants were professionals (630) which included doctors, paramedical, IT sector and finance, hospitality and human resource. Other participants included teachers, businessmen, home-makers, students, farmers, police officers and from other professions (Table 1). On analyzing the survey questionnaire, in the first section, majority of people responded in predicting the pandemic to increase in upcoming time and many people declared that this life will be a new normal, $23 \%$ people said life will never be normal in near future, about $27 \%$ people were not sure (Table 2). $69 \%$ people were concerned regarding their family's health, though $13.2 \%$ people felt they are safe. When people were questioned regarding their finances and economics, $28 \%$ were quite stressed regarding retaining their job, $34.52 \%$ were little stressed regarding their job, though 3.5\% (50) people admitted they have already lost their jobs. $55.48 \%$ people admitted that they will limit their expenses, will purchase only necessary things, $33.40 \%$ people said they will 
limit their expenditure as their earning has reduced; only $2.09 \%$ people said they will spend liberally as life is so unpredictable and they will not think of financial status (Table 3). When they were enquired about government policy that how should government handle the future situation as tremendous rising number of cases, $36.89 \%$ people suggested that complete lockdown should be implemented though $41.02 \%$ people were of the opinion that lockdown should be implemented in high risk zones. Only 6.7\% people didn't favor lockdown and others were not sure if it will be helpful or not (Figure 1).

In the pandemic control and treatment section, majority of the people about $76-80 \%$ were of the opinion that following social distancing, wearing masks whenever step-out of the house and avoiding going to crowded places may help in preventing viral spread (Figure 2). Though 4.5\% people were disheartened regarding control of disease and they felt nothing is going to work. Regarding alternative therapies, when they were inquired, $15.79 \%$ people were sure that it will work in the treatment of patients, $20.33 \%$ people felt it can work to some extent, though $20.12 \%$ people felt there is no role of homeopathy and Ayurveda in treating COVID-19, rest of the participants weren't sure. More than 50\% people were thinking that it may take around one year to receive vaccine, around $32 \%$ were of the opinion that it may come within next 2-4 months though $9.71 \%$ felt we may not receive at all (Table 4).

Some important suggestions given by the participants were

"All the sectors should be supporting each other than blaming each other for their misery. Government should offer financial support to citizens/institutions. We should come together as people and genuinely change our lifestyles in keeping with the environment. We should restrict our movement to bare minimum for the next three months at least. New normal should be accepted in the interest of everyone."

"1.Identifying hot spots along with containing the spread needs to be the key... 2.Educating people about the new way of life. That's the need of the hour... 3. Mandating the app Aarogya Setu or similar...4. Ensuring people come out and say they are unwell... 5. Encouraging home quarantine and treatments for affected people. 6. Stiffening laws for people not following norms... 7.Ramping up medical facilities."

"Central Govt. /state Govts. should co-operate public without being bias only with migrants/ weaker section/minorities etc. Schools remain closed or started in two shifts to minimize the strength of students in classroom. Govt. also have some package for middle class people. Medical staff should also cooperate with public."

"Directing our entire efforts in Containing the infection in containment zones in form of strict sealing of the area with no mobility, compulsory screening for all and door to door education \&amp; surveillance campaigns and ramping up hospitals in the vicinity"

\section{Discussion}

As people have enough knowledge and update regarding these issues, we conducted this survey to check their futuristic opinions on disease trends, their economic and financial concerns, their thoughts about government policies regarding implementation of lockdown in the upcoming future and how they see future treatment options.

From this survey we could see that Indian people are aware about disease trends in the coming future, they are mentally prepared now that this pandemic is going to increase further. This recent trend of disease rise is increasing apprehension in them regarding their own and their family's health. We could asses that people are getting prepared to understand the situation that how to handle their finances and economics. But at the same-time we observed that many people were stressed about retaining their jobs though stress level was variable amongst them and about 3.5\% people admitted that they had already lost their job. Another trend visualized during this survey analysis was that people were clear to reduce their expenditure and don't want any unnecessary shopping. That's the better way for people for their personal financial handling but if we understand our country's economy then this trend is not good. This is actually affecting business and overall trade, less demand, less production leading to less supply of goods, requiring lesser people/ workers at factories leading to more job loss and affecting public's economic and mental health. With lesser buying capacity of the buyers, lesser people needed for transport of goods, reduced need of transport vehicles or need of petrol and diesel.

In recent past, to stop community transmission, India followed a strict lockdown from late March till May, then it continued in some selected states and cities. According to Saheli RC 2020, initially the number of cases were seen rising in India, though at a slow pace. After a few extensions, the country finally lifted the lockdown at the end of May. Some states and 
regions though followed restrictions in place. As per number of new cases in some areas, many districts are demarcated into low-risk and high-risk zones. Activities in the high-risk zones remain restricted, though low-risk areas are resuming their economic activity slowly. Nationwide restrictions have grounded economic activities of the country and GDP has gone down in last three months. After unlock period from $1^{\text {st }}$ June, it started rising slowly, but not picked up. As in the unlock period, cases started rising steeply in our country, total number of cases in India as per $6^{\text {th }}$ August, 2020, 2.03 Million confirmed cases are there and 1.38 million recovered. Maharashtra remains the worst affected Indian state, with its cumulative cases at 468000 followed by Tamil Nadu 273,000, then Andhra Pradesh 186,000, Karnataka 151000 and the fifth state Delhi 140,000 (fallen from number two). The death toll in India is comparatively low at 41585 . It may be because of multiple reasons, better climate conditions, early lockdown lead to late entry of virus to our country, as a result of which low attenuation of the virus, better policy implementation by our government, more treatment options available these days and better preparedness by our people. "Recovery rate and incidence of death both improved a little more this week," the Citi economists said. According to Nicola M et al., 2020, "Even as confirmed cases would likely rise further, continued improvement in recovery rate and a low mortality rate would be key factors for the economy to open up as India 'learns' to live with the virus".

As per an article of The Indian Express $16^{\text {th }}$ May 2020, these lockdowns confined millions of citizens to their homes, shutting down businesses and ceasing all types of economic activity. The global economy is expected to reduce by over 3 per cent according to the International Monetary Fund (IMF) in 2020. It is the steepest slowdown of economy. In view of falling GDP, our Finance Minister announced packages for various people to uplift their business and help dwindling economy. Basu and Bhatt, 2020 highlighted in their article that India is among seven Asian countries of the continent having $85 \%$ of total COVID19 cases of the continent and number is rapidly on rise therefore matter of a major concern for public and the government.

Despite downfall of economy and loss of finances, in our survey majority of the participants felt the need to put our country to lockdown again, $36.89 \%$ responded in favor of complete lockdown and $41 \%$ responded in favor of partial lockdown in high risk zones. It clearly suggests that the because of the fear of rapid virus spread, people are ready to compromise on their finances and feel the need that lockdown should be implemented again. Most of the people admitted that besides lockdown we need to wear masks, maintain social distancing and avoid crowded places to break the chain of this pandemic.

This survey clearly tells about the public psychology regarding this COVID-19 pandemic and on discussion regarding alternative treatments and vaccination, about $20 \%$ people were sure of effects of homeopathy and Ayurveda, though others weren't sure. Regarding vaccine development majority of people felt it may take another one year for its development and availability for people.

Therefore, in our study we have highlighted the importance of public opinions and understanding their problems and psychology. This study has highlighted the importance of mental and economic health of people. Our study also enquired regarding the preparedness of people for the future lockdown as well as checked their knowledge about prevention of spread of pandemic. We asked for their suggestions as well as this study was conducted in educated people, professionals and as well uneducated people as well to reduce the bias of dealing with one type of strata. The limitations of our study was the sample size, as our study represents the public opinion, therefore a larger sample size would have been better to reach up to some conclusion. Second limitation of our study is that we kept a small questionnaire focusing mainly on public preparedness and their futuristic approach. At present our country, in fact the whole world is going through extreme emotional and financial crisis. In future, further studies dealing with the mental health of people in a larger sample need to be conducted. Such surveys directly dealing with people pertaining to COVID-19 pandemic may help policy makers of our country to take some strong decisions to prevent its spread and to avoid financial and emotional crisis. We wish and expect our country to come out of this catastrophe very soon and smoothly.

\section{Conclusion}

This short survey helped us to understand public psychology and thoughts regarding COVID-19 pandemic future perspectives and what they expect their life in near future and family's health. Their concern regarding their jobs, finances was also discussed. Most of the people agreed upon the routine precautions to be taken to control pandemic but most of the people agreed upon the need of lockdown implementation again. We expect our study will help the policymakers in deciding their future course of action. We want India to be an equitable society where people are safe and their job and income is secure. We need to get together in these difficult times and follow precautions and support government as much as possible. 


\section{References}

[1] Coronavirus has become a pandemic, WHO. (n.d). Retrieved from https://www.nytimes.com/2020/03/11/health/coronaviruspandemic-who.html.

[2] Dubey, S., Biswas, P., Ghosh, R., Chatterjee, S., Dubey, M. J., Chatterjee, S., ... \& Lavie, C. J. (2020). Psychosocial impact of COVID19. Diabetes \& Metabolic Syndrome: Clinical Research \& Reviews.

[3] Explained Desk. Covid-19 impact: According to IMF, the global economy is expected to shrink by over 3 per cent in 2020 - the steepest slowdown since the Great Depression of the 1930s. The Indian Express- 16 $6^{\text {th }}$ May, 2020. Explained: How Covid-19 has affected the global economy

[4] Gilbert, M., Pullano, G., Pinotti, F., Valdano, E., Poletto, C., Boëlle, P. Y., ... \& Gutierrez, B. (2020). Preparedness and vulnerability of African countries against importations of COVID-19: a modelling study. The Lancet, 395(10227), 871-877.

[5] Haleem, A., Javaid, M., Vaishya, R., \& Deshmukh, S. G. (2020). Areas of academic research with the impact of COVID-19. The American Journal of Emergency Medicine. https://doi.org/10.1016/j.ajem.2020.04.022

[6] Kaushik Basu, Ela R. Bhatt. (2020). Crisis also brings opportunity for building a nurturing economy- Our economic and political policies must not be ends in themselves, but instruments for building a society that is secular, inclusive and nurturing, where people of all religions, caste, race and gender feel wanted and at home. The Indian Express.

[7] Nicola, M., Alsafi, Z., Sohrabi, C., Kerwan, A., Al-Jabir, A., losifidis, C., ... \& Agha, R. (2020). The socio-economic implications of the coronavirus pandemic (COVID-19): A review. International journal of surgery (London, England), 78, 185. https://doi:10.1016/j.ijsu.2020.04.018

[8] Saheli Roy Choudhury. India shut down its economy to contain the coronavirus. It's now one of the most affected countries. Asia Economy.CNBC.Published Sun, Jun 14 20208:56 pm. 2020.

[9] Xiang, Y. T., Li, W., Zhang, Q., Jin, Y., Rao, W. W., Zeng, L. N., ... \& Hall, B. J. (2020). Timely research papers about COVID-19 in China. The Lancet, 395(10225), 684-685.

\section{Table 1. Demographic Profile}

\begin{tabular}{|c|c|c|}
\hline Age (Mean \pm SD); Range & $36.7 \pm 10.6$ & $8-85.0$ \\
\hline Country & $\begin{array}{l}\text { No. of } \\
\text { Participants }\end{array}$ & Percentage \\
\hline India & 1384 & $96.70 \%$ \\
\hline $\begin{array}{l}\text { Non-Resident Indians (USA, Canada, Australia, } \\
\text { Florida, Nigeria, Singapore) }\end{array}$ & 47 & $3.30 \%$ \\
\hline Total & 1431 & $100.00 \%$ \\
\hline \multicolumn{3}{|l|}{ Occupation } \\
\hline Businessman & 154 & $10.76 \%$ \\
\hline Farmer & 18 & $1.25 \%$ \\
\hline Home-makers & 90 & $6.29 \%$ \\
\hline Other & 218 & $15.23 \%$ \\
\hline Police officer & 4 & $0.30 \%$ \\
\hline $\begin{array}{l}\text { Professional } \\
\text { (Medical/Paramedical/IT/Hospitality/Finance/Human } \\
\text { resource) }\end{array}$ & 630 & $44.02 \%$ \\
\hline Student & 99 & $6.90 \%$ \\
\hline Teacher & 218 & $15.23 \%$ \\
\hline Total & 1431 & $100.00 \%$ \\
\hline
\end{tabular}


Table 2- Public Perspectives regarding upcoming future and health

\begin{tabular}{|c|c|c|}
\hline What do you think about COVID Pandemic in coming months? & No. of Participants & Percentage \\
\hline It will decrease & 132 & $9.20 \%$ \\
\hline It will increase & 1075 & $74.80 \%$ \\
\hline It will remain same & 75 & $5.20 \%$ \\
\hline No idea & 149 & $10.40 \%$ \\
\hline Total & 1431 & $100.00 \%$ \\
\hline \multicolumn{3}{|l|}{ What do you think about life in Covid-19 pandemic in coming months? } \\
\hline Can't say & 394 & 27.45 \\
\hline It's a new normal & 574 & $40.11 \%$ \\
\hline Life will be same as earlier & 133 & $9.29 \%$ \\
\hline Life will never be normal & 330 & $23.06 \%$ \\
\hline Total & 1431 & $100.00 \%$ \\
\hline \multicolumn{3}{|c|}{ How much you are concerned regarding you and your family's health? } \\
\hline A lot & 991 & $69.25 \%$ \\
\hline Not much & 29 & $2.00 \%$ \\
\hline To some extent & 222 & $15.51 \%$ \\
\hline We are safe & 189 & $13.20 \%$ \\
\hline Total & 1431 & $100.00 \%$ \\
\hline
\end{tabular}

Table 3- Financial Concerns of Public

\begin{tabular}{|l|l|l|}
\hline $\begin{array}{l}\text { How much are you concerned regarding retaining } \\
\text { your job due to COVID pandemic? }\end{array}$ & No. of Participants & Percentage \\
\hline Already lost & 50 & $3.50 \%$ \\
\hline Little stressed & 494 & $34.52 \%$ \\
\hline Not much & 483 & $33.75 \%$ \\
\hline Quite stressed & 404 & $28.23 \%$ \\
\hline Total & 1431 & $100.00 \%$ \\
\hline $\begin{array}{l}\text { What do think about handling money matters in } \\
\text { the near future? }\end{array}$ & & \\
\hline
\end{tabular}




\begin{tabular}{|l|l|l|} 
To limit expenses as earning has decreases & 478 & $33.40 \%$ \\
\hline $\begin{array}{l}\text { Will buy only necessary things or keep delaying any } \\
\text { new purchase }\end{array}$ & 794 & $55.48 \%$ \\
\hline $\begin{array}{l}\text { Will spend liberally without any tension as life is } \\
\text { unpredictable }\end{array}$ & 30 & $2.09 \%$ \\
\hline $\begin{array}{l}\text { Won't change my lifestyle, will continue same as i } \\
\text { was doing }\end{array}$ & 129 & $9.00 \%$ \\
\hline Total & 1431 & $100.00 \%$ \\
\hline
\end{tabular}

\section{Table 4- Public Opinions Regarding Treatment options}

\begin{tabular}{|l|l|l|}
\hline $\begin{array}{l}\text { As per your opinion, will Ayurveda and } \\
\text { Homeopathy work in this disease? }\end{array}$ & Number of Participants & Percentage \\
\hline It may work, not sure & 626 & $43.74 \%$ \\
\hline Not at all & 288 & $20.12 \%$ \\
\hline Yes, can work to some extent & 291 & $20.33 \%$ \\
\hline Yes, will work definitely & 226 & $15.79 \%$ \\
\hline Total & 1431 & $100.00 \%$ \\
\hline When do you think we may get vaccine? & & \\
\hline By Mid-September & 327 & $22.85 \%$ \\
\hline It may take an year & 832 & $58.14 \%$ \\
\hline Next 1-2 months & 133 & $9.29 \%$ \\
\hline We may not get at all & 139 & $9.71 \%$ \\
\hline Total & 1431 & $100.00 \%$ \\
\hline
\end{tabular}


Figure 1. Public Opinions regarding Government Policies on Implementation of Further Lockdown.

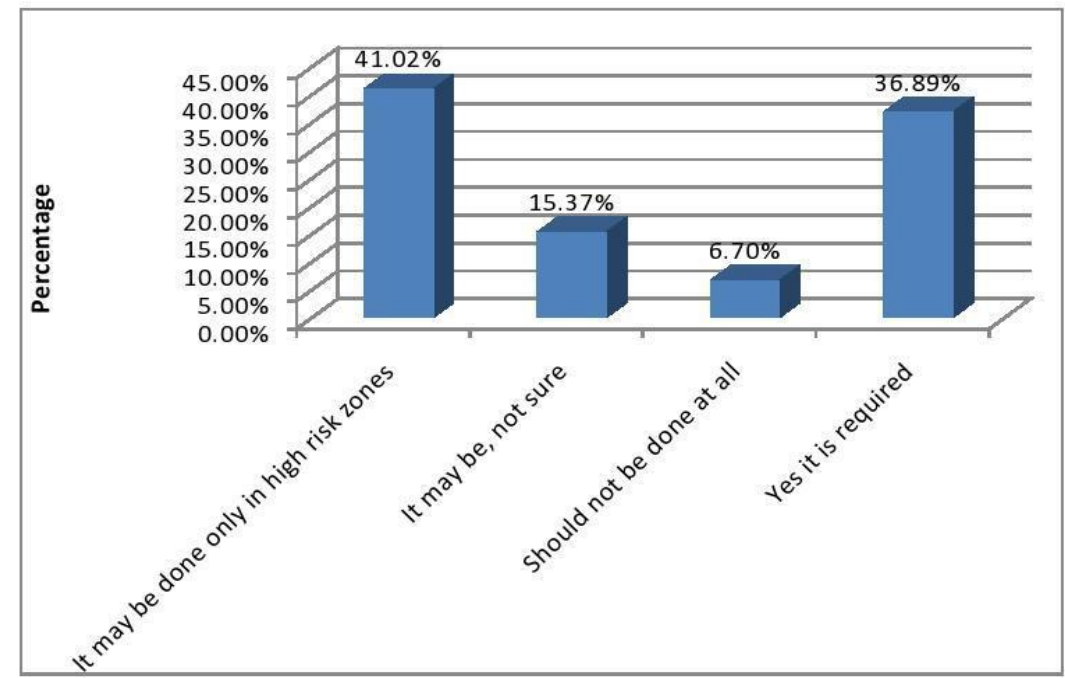

Figure 1. 
Figure 2- Public opinions regarding avoiding spread of virus

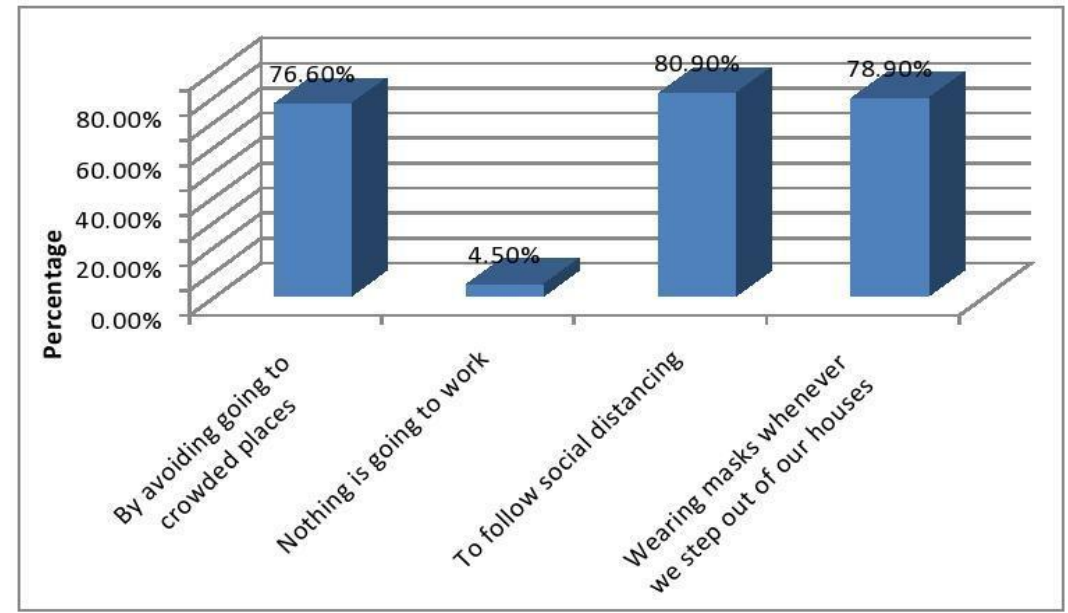

Figure 2 